\title{
Adapting a Circular Economy in Regional Strategies of the European Union
}

\author{
Susanna Vanhamäki ${ }^{1}$, Satu Rinkinen ${ }^{2}$ and Kati Manskinen ${ }^{3, *}$ \\ 1 School of Energy Systems, LUT University, Mukkulankatu 19, FI-15140 Lahti, Finland; \\ susanna.vanhamaki@student.lut.fi \\ 2 School of Engineering Science, LUT University, Mukkulankatu 19, FI-15140 Lahti, Finland; \\ satu.rinkinen@lut.fi \\ 3 LAB University of Applied Sciences, Mukkulankatu 19, FI-15140 Lahti, Finland \\ * Correspondence: kati.manskinen@lab.fi; Tel.: +358-50-301-8167
}

check for

updates

Citation: Vanhamäki, S.; Rinkinen, S.; Manskinen, K. Adapting a Circular Economy in Regional Strategies of the European Union. Sustainability 2021, 13, 1518. https://doi.org/10.3390/ su13031518

Academic Editor: Elena Cristina Rada Received: 7 December 2020

Accepted: 27 January 2021

Published: 1 February 2021

Publisher's Note: MDPI stays neutral with regard to jurisdictional claims in published maps and institutional affiliations.

Copyright: (c) 2021 by the authors. Licensee MDPI, Basel, Switzerland. This article is an open access article distributed under the terms and conditions of the Creative Commons Attribution (CC BY) license (https:// creativecommons.org/licenses/by/ $4.0 /)$.

\begin{abstract}
The transition towards a sustainable circular economy (CE) model is seen as a solution to keep the consumption of the earth's resources within planetary boundaries. In the regional context, the $\mathrm{CE}$ is promoted through various policy actions, one being the smart specialisation concept. This paper provides a novel approach to examining the spatial adaption of a CE through a conceptual framework of research and innovation strategies for smart specialisation (S3) in Europe. This interdisciplinary research presents a multi-country comparison of S3 implementation in Europe in 12 regions that have defined the $\mathrm{CE}$ as a priority area. The data consist of interviews with representatives of organisations responsible for the regional S3 process. The findings indicate that a political demand exists for proceeding further with the construction of transformative activities involving the $\mathrm{CE}$, but the models and stages of implementation vary. In addition, most regions still struggle with building specific monitoring and evaluation measures and mechanisms for the CE. Despite these challenges, promoting the $\mathrm{CE}$ as a strategic priority through the S3 process has, at least in some regions, helped define the $\mathrm{CE}$ targets and actions by focusing on existing regional assets and future potential.
\end{abstract}

Keywords: circular economy strategies; regional policy; smart specialisation

\section{Introduction}

The global consumption of different materials is expected to double within the next 40 years [1]. The transition towards a circular economy (CE) is seen as a solution for sustainable consumption issues. The CE can be defined as an economic system based on closing material loops and maintaining the value of products and resources for as long as possible [2-4]. In 2015, the European Commission (EC) released an action plan concerning the European Union's (EU) transition towards the CE [5]. The EC's action plan stated that broad, long-term commitment is needed at all levels of government to develop the $\mathrm{CE}$, that is, with the local, regional and national authorities acting as key agents in enabling the transition [5]. The political importance of developing the $\mathrm{CE}$ has been increasing in the EU since 2015. The EU's new CE action plan published in 2020 addresses the need to accelerate the transition towards regenerative growth through a CE model that gives back to the planet more than it takes and keeps the consumption of the earth's resources within planetary boundaries [6].

In addition to saving natural resources, the transition towards the CE develops a sustainable, low-carbon, resource-efficient and competitive economy through increasing growth and jobs [5]. Because the $\mathrm{CE}$ has been widely perceived as a solution for economic growth and environmental sustainability, it has been adopted by several governments and businesses. Other similar concepts of operationalising sustainable development for businesses include the green economy and green growth [1,7]. 
The emergence of the CE and research and innovation strategies for smart specialisation (S3) has developed in tandem in European regions over the last years [5,8]. The S3 concept was introduced as part of the EU's cohesion and innovation policy to ensure the targeted use of European Structural Funds (ESF) and to guide investments in research and innovation by focusing on the fields with the most competitive advantage and future potential [8,9]. Some regions in Europe have recognised the possibility of combining their S3 and CE goals. Selecting regional priority areas for development is one of the key steps of the S3 process [8]. This paper provides a novel approach to examining the adaption of the $\mathrm{CE}$ in the European regions that have defined the CE as an S3 priority area.

The aim of this research is not to study whether S3, as such, is a useful way of realising cohesion policy or regional innovation policy. Rather, the S3 is viewed as an existing policy approach under which the concretisation of regional CE targets is studied. The study defines the thematic priority areas, along with the existence of a more detailed strategy, or 'roadmap', regarding the CE and, furthermore, whether the roadmap has been defined in an action plan or through actions.

This paper aims to answer how S3's thematic priority areas related to the CE are concretised and implemented in regional objectives or priorities (roadmaps) and actions (action plans). The paper is organised as follows. First, a brief theoretical background of the CE and S3 concepts is presented. Second, the research approach, data collection method and analytical approach are introduced. Third, the key findings on how the CE-related thematic priorities are concretised in S3, as well as examples of regional implications, are described. The paper concludes with a discussion of the challenges and possibilities of combining S3 with the CE. Moreover, areas for future research are suggested.

\section{Theoretical Background}

\subsection{Towards Systemic Change of the CE}

The concept of the CE has drawn increasing interest since 2012, when the initial CE report by the Ellen MacArthur Foundation was published [10]. However, trending concepts tend to diffuse in their meaning, and researchers claim that this has also happened to the CE [4]. Numerous attempts have been made to define the CE concept. The term's varying definitions may generate confusion and reduce opportunities for international cooperation [11]. Kirchherr et al. [4] analysed 114 definitions of the CE concept. They highlighted the significance of the systemic change of the CE, even though, based on their research, only around $40 \%$ of the definitions conceptualise the CE from a systems perspective.

The systemic change of the CE operates at all levels: the micro level (products, companies, consumers), the meso level (ecosystems, industrial symbiosis) and the macro level (city, region, nation) [12-16]. To manage the CE transition on different systemic levels, CErelated measuring instruments need to be used. Saidani et al. [16] classified 55 circularity indicators into 10 categories based on, for instance, the level of implementation (micro, meso, macro), the CE loops (maintain, reuse, remanufacture, recycle) and the perspective of circularity (actual, potential). Their research showed that CE indicators exist, but holistic indicators and knowledge on the usability of the different types of indicators are still lacking.

The CE concept as a policy instrument is an increasingly popular regulatory policy to address. In China, the CE is promoted as a top-down national political objective, while in other areas and countries, such as the EU, Japan and the United States, it is seen as a tool for designing bottom-up environmental and waste management policies [3]. However, the importance of top-down political development of the CE has been increasing in the EU as well. EU-level actions to develop the CE have inspired national debates [17]. Several EU member states have already adopted or are in the process of adopting national CE strategies [18]. The EU's national-level strategy actions have been repeated or are in the process of being replicated at the regional and local levels, bringing the transition to the $\mathrm{CE}$ closer to action in businesses and among citizens [19]. 
Within business, the investment in clean technologies is considered an essential step towards the CE [20]. Clean technologies are new industrial processes or modifications of existing ones that are intended to reduce the impact of production activities on the environment, including through reducing the use of energy and raw materials [21]. In the EU, the adoption of clean technologies is being accelerated through various policy actions. At the beginning of 2020, the EC presented the European Green Deal Investment Plan, which will mobilise at least a trillion euros of sustainable investments over the next decade [22].

Despite the relevance of the $\mathrm{CE}$ within the current policy and economic debate, the concept remains open to interpretation and has received criticism. Saltelli et al. [23] have claimed that a truly circular economy is not going to happen in the near future. Giampietro and Funtowicz [24] see the CE concept as 'socially constructed ignorance' where an indepth sustainability debate is set aside. The CE should rely on the $4 \mathrm{R}$ framework of reduce, reuse, recycle and recover [25]. However, the findings of Kirchherr et al. [4] indicate that only $3-4 \%$ of $C E$ definitions reflect the $4 R$ framework, particularly with regard to $C E$ implementation based on definitions that do not outline the reduce stage. Although a properly used $\mathrm{CE}$ is based on the $4 \mathrm{R}$ framework, it may become very problematic due to the conventional definition of material flows [26]. Furthermore, in circular systems, the concept of waste is changing; for example, material may turn into an energy resource with variable economic values, and the waste can be transformed into by-products. The concept of waste is related to culture, society, community, history and the level of societal development. Thus, all CE proposals and suggestions should be placed into and considered within their temporal, spatial and cultural contexts [26].

\subsection{From Planning to Action in Smart Specialisation}

The need for investing more in research and innovation was recognised as a crucial part of boosting the European economy in the Europe 2020 strategy $[8,9]$. Thus, the S3 concept has been an integral part of the EU's cohesion policy framework during the latest budget period of 2014-2020, and the S3 framework has been widely applied in EU member countries. Defining a national or regional S3 was set as a requirement for allocating EU research and development funding [8,9]. The aim is to channel research and innovation resources to selected priority areas which are seen to have the greatest potential for the region to excel in the future. When analysing and selecting the priority areas, the regions are encouraged to go beyond the traditional sectoral approach and utilise the related variety $($ see $[27,28]$ ) type of diversification within a priority area, meaning diversification into related areas based on new technologies or processes [8]. The idea of the S3 process is to build on existing regional structures and transform these structures utilising new related research activities [29]. The post-2020 cohesion policy will support and encourage regions to improve their existing S3 and interregional cooperation [30].

Previous research has provided a significant amount of knowledge, examples and experiences from both the theoretical (e.g., [28,31,32]) and practical (e.g., [33-35]) points of view. Based on the previous literature, the challenge of implementing S3 policies into practice in a variety of different regions is evident, which has been the case since the concept was launched [36]. Case studies of single regions or countries implementing S3 do exist (e.g., $[33,34,37])$, as do research papers on the regional comparisons of the S3 preconditions and processes as well as the implementation of S3 processes in the different countries (e.g., [25,38,39]), but what is mostly lacking are multi-country comparisons [40].

One of the often-discussed challenges of S3 is the variety of regional capabilities for S3 implementation due to their differences in size, economic conditions, institutional capacity, industrial structure and governance issues [36,38,39,41,42]. This raises the question: For which type of region is the S3 approach most beneficial? Hassink and Gong [29] revealed this dilemma in more detail and highlighted the 'regional innovation paradox' [43,44], which can hinder the successful application of S3 in less favoured regions. Regarding the question of which type of region the S3 approach would be most beneficial for, Foray [45], 
one of the original developers of the S3 concept, admitted that S3 may not be the most beneficial policy framework for the most advanced and largest (in terms of GDP per capita) regions nor for the regions at the other end of the spectrum. However, a great number of intermediate regions within and outside Europe could benefit from S3 [45].

The RIS3 Guide [8] is a methodological guide and an orientation document for policymakers and implementing bodies when designing and implementing S3. The guide presents the S3 design as a six-step process - not necessarily a linear one-that includes (1) analysing the regional context and innovation potential, (2) ensuring participation, (3) creating a future vision for the region, (4) identifying priorities, (5) creating a suitable policy mix and (6) monitoring and evaluating mechanisms. However, in his response to Hassink and Gong [29], Foray [45] suggested simplifying the S3 process down to three steps: (1) identifying the thematic priority areas, (2) translating these priority areas into transformational roadmaps and (3) implementing the transformational activities with an action plan. The first phase has a clear (top-down) planning aspect, whereas the following two transformative activities are influenced by the (bottom-up) self-discovery aspect of the entrepreneurial discovery process (EDP), which was originally also an essential part of the selection of the regional priority areas. The EDP is an interactive process bringing together regional stakeholders $[9,45]$. The process of creating a roadmap and action plan is also what differentiates a region from others within the same priority area, as these activities are based on region-specific capacities, potentials and opportunities. Foray [45] emphasised the second step of creating transformational roadmaps for the selected priority areas and noted that many regions that have successfully conducted their prioritisation task have found it difficult to concretise and implement these priorities. Steps two and three focus on the construction and development of transformative activities through a collection of projects that lead the transformation path in the region. These projects have a clear link to funding in the EU, especially to ESIF. Following the logic of the EDP, the projects and the way these transformative activities are developed also require appropriate monitoring, measuring and evaluation mechanisms to ensure an understanding of the degree of progress or the need for readjustments [45].

In Europe, some regions have seen it possible to combine their S3 and CE goals and ambitions. While the EU supports CE as a potential and necessary path for development, regions seek to identify and develop their competitive advantages through S3. Adopting CE should be aligned with strategic documents and identified strengths and needs, which are set in the S3. If a certain topic is defined as a priority in the S3 there should be a strong connection to how it is concretised in the region through roadmaps, activities and funding.

The current research aims to discover how various regions have concretised S3's thematic priority areas related to the $\mathrm{CE}$, and it provides examples of effective ways to enable the implementation of CE priorities within the regional context. Despite the already wide adoption of the policy approach, S3 processes face many challenges, including implementation challenges $[31,46]$. Although several papers have been published on S3 building processes and implementation challenges (see e.g., [35,47]), examples of best practices of implementation processes are still scarce. Research on how CE has been implemented or concretised though the S3 process is, to the best of our knowledge, not found in the literature. The current paper aims to fill this research gap.

\section{Materials and Methods}

To discover the logic behind how S3's related to the CE have been concretised in the regional policy, a qualitative research approach that included thematic analysis was applied. In thematic analysis, a data set is systematically processed, identified and organised in search of themes, that is, patterns of meanings [48], which enable the researcher to better understand and interpret the collected data. Furthermore, case overviews can be created, and accordingly, individual cases can be selected for in-depth analyses [49]. This method is suitable for identifying commonalities in the way a topic is presented [48]. In qualitative research, the data are analysed alongside the data collection as thematic patterns 
emerge [50]. The data analysis is also iterative, requiring several loops, during which the researcher gains greater familiarity with the data. For example, the relevant data related to a specific theme might not always be found in the context of the exact question asked. The guiding principle in the analysis is the interchange between the collected data and theoretical knowledge [49].

In this research, the data collection was conducted mainly through semi-structured interviews. In semi-structured, or semi-standardised, interviews, researchers orient themselves according to a predefined frame, but one that provides freedom in the formulation of questions [51]. Semi-structured interviews enable concentration on a specific theme and allow for discussion on the topics. They combine both open-ended and more theoretically driven questions that aim to explore both the experience of the interviewee and the data based on the existing constructions [50]. In this study, the semi-structured approach allowed the interviewer to ask-in addition to the questions listed in the interview frame-more in-depth questions about the regional strategy formation and processes in cases where it was found necessary. This helped strengthen the quality of the interview data.

The EC Joint Research Centre's (JRC) Smart Specialisation Platform and its tool for visualising public investment priorities for innovation across Europe, Eye@RIS3, gives an overview of the regions' priorities [52]. The purpose of the database is to support strategy development and find partners for collaboration. However, it also enables the comparison of S3 across Europe to achieve a better understanding of how regions and countries are developing their policies and innovation priorities. Even if the S3 approach is a requirement of research and innovation investments for the programming period 2014-2020 [35] registration on the JRC's platform is voluntary although desirable. Regions are advised to join the S3 platform on the most relevant NUTS level with respect to innovation strategies and manging ESF [53]. The platform covers almost all territories of the EU member states. However, there are regional differences. Large countries have not registered on NUTS 1 level but rather on NUTS 2 or 3, which means that if certain regions have not been active in the S3 they are missing from the platform, this concerns for example a few regions in Germany, France and Greece [54].

The sample regions on which this research focuses were identified from the Eye@RIS3 database on 10 May 2019. The regions were searched with the keyword 'circular economy'. On that date, 14 European regions on Nomenclature of Territorial Units for Statistics (NUTS) levels 1-3 described thematic priorities related to the CE. Due to the low number of hits, the decision was made to keep a wide focus that included all the mentioned NUTS levels. Responsible persons in these regions were contacted though email, and a telephone interview was proposed. In the end, 11 regions accepted the interview invitation, and one additional region proposed replying through email. This indicates a relatively high rate of involvement of the regions in focus. All the interviews were conducted by telephone, except in the Päijät-Häme region, where the interview was conducted face to face. The persons interviewed in the regions represented the organisations responsible for the regional S3 process. Usually, the interview was conducted with one person, but in three of the regions, two or three people attended the discussion. The interviews were conducted in English, except for one that was done in Finnish at the interviewee's request. The interviews lasted 20-50 min. Table 1 provides information on the regions that participated in the research, their organisations, dates of the interview and NUTS levels.

Semi-structured interviews were utilised as the primary data source to allow for concentration on the specific themes and were carried out in a conversational style. This enabled the research to target the key persons involved in the S3 processes and to focus on the specific characteristics of CE implementation in each region. The questions asked from each region covered the background of the S3 priorities related to CE, with focus on regional priorities, updating process, actions, and funding. The interview questions are presented in the Appendix A. For this, paper questions 4-9 were in focus. In some cases, clarifying questions were sent afterwards to the interviewees through email. To ensure the anonymity of the interviewees, all quotes and in-text citations have been given a code 
number (e.g., (1), (2)). The numbers do not reflect the alphabetical order or any other order. In addition to the interviews, detailed data retrieved from the JRC's Smart Specialization Platform were utilised [52].

The interviews were recorded and transcribed; they were then classified and coded based on the theoretical framework. The content related to the region's CE concept in S3 as well as the EDP was identified. Subsequently, this content was coded and summarised, and finally, it was compared to the conceptual framework of S3.

Table 1. Study regions.

\begin{tabular}{|c|c|c|c|c|}
\hline Country & Region & $\begin{array}{l}\text { Interviewed } \\
\text { Organisation }\end{array}$ & $\begin{array}{l}\text { Date of } \\
\text { Interview }\end{array}$ & NUTS Level \\
\hline Belgium & $\begin{array}{l}\text { Brussels-Capital } \\
\text { Region }\end{array}$ & Innoviris & 1 July 2019 & NUTS 2 \\
\hline Denmark & $\begin{array}{l}\text { Central } \\
\text { Denmark }\end{array}$ & $\begin{array}{l}\text { Central Denmark } \\
\text { Region }\end{array}$ & 17 June 2019 & NUTS 2 \\
\hline Finland & $\begin{array}{l}\text { Southwest } \\
\text { Finland }\end{array}$ & $\begin{array}{l}\text { Regional Council of } \\
\text { Southwest Finland }\end{array}$ & 26 August 2019 & NUTS 3 \\
\hline Finland & Häme & $\begin{array}{c}\text { Regional Council of } \\
\text { Häme }\end{array}$ & 17 June 2019 & NUTS 3 \\
\hline Finland & Päijät-Häme & $\begin{array}{l}\text { Regional Council of } \\
\text { Päijät-Häme }\end{array}$ & 31 May 2019 & NUTS 3 \\
\hline Finland & Satakunta & $\begin{array}{l}\text { Regional Council of } \\
\text { Satakunta }\end{array}$ & 19 June 2019 & NUTS 3 \\
\hline Germany & Berlin & $\begin{array}{l}\text { Senate Department for } \\
\text { Economics, Energy and } \\
\text { Public Enterprises }\end{array}$ & 5 June $2019^{1}$ & NUTS 2 \\
\hline Germany & Brandenburg & $\begin{array}{l}\text { Economic Development } \\
\text { Agency Brandenburg }\end{array}$ & 1 July 2019 & NUTS 2 \\
\hline Luxembourg & Luxembourg & $\begin{array}{l}\text { Ministry of Economy } \\
\text { South Muntenia }\end{array}$ & 11 July 2019 & NUTS 1 \\
\hline Romania & Sud-Muntenia & $\begin{array}{l}\text { Regional Development } \\
\text { Agency }\end{array}$ & 14 June 2019 & NUTS 2 \\
\hline Slovenia & Slovenia & $\begin{array}{l}\text { Government Office for } \\
\text { Development and } \\
\text { European Cohesion } \\
\text { Policy }\end{array}$ & 17 June 2019 & NUTS 1 \\
\hline Spain & Basque Country & Basque Government & 12 July 2019 & NUTS 2 \\
\hline
\end{tabular}

${ }^{1}$ Email reply.

\section{Results and Discussion}

\subsection{Conceptual Framework of the Study}

The policy-based conceptual framework of this study presented in Figure 1 was created based on the literature background of S3 and leans particularly towards the policy lessons and suggestions presented by Foray [45]. The framework summarises the updated S3 process and highlights the practical implementation phase after thematic priority areas have been defined. Although the steps are presented here as a simplified linear process, in practice, the process phases partly overlap and include feedback loops between different phases. The monitoring and evaluation phase refers to the monitoring and evaluation of the concrete actions and how the set targets have been reached. It should also be noted that the S3 strategy as a whole requires continuous evaluation regarding the chosen priority areas and the desired direction of change. A regular review of the priorities allows for flexibility in changing economic and other framework conditions [34]. 


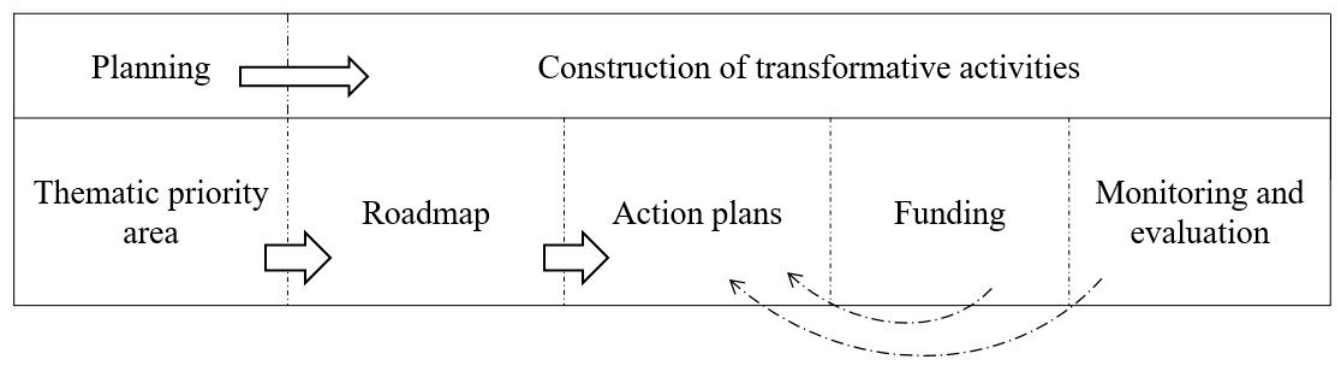

Figure 1. Conceptual framework of the study.

The novel approach of this paper lies in analysing the regional research data through the conceptual framework of the S3. The paper explains the stage of the CE adaption in the European regions that have defined the $\mathrm{CE}$ as an $\mathrm{S} 3$ priority area. The results of the interviews are presented in Table 2 following the structure of the conceptual framework. This allows a coherent examination of the varying regional approaches through a literature based S3 framework.

Table 2. Thematic priority areas of the study regions and the construction of transformative activities related to the (CE).

\begin{tabular}{|c|c|c|c|c|c|c|}
\hline \multirow[b]{2}{*}{ Country } & \multirow[b]{2}{*}{ Region } & \multirow{2}{*}{$\begin{array}{c}\text { Planning } \\
\text { Thematic } \\
\text { Priority Area }\end{array}$} & \multicolumn{4}{|c|}{ Construction of Transformative Activities } \\
\hline & & & Roadmap & Action Plans & Funding & $\begin{array}{l}\text { Monitoring and } \\
\text { Evaluation }\end{array}$ \\
\hline Belgium & $\begin{array}{l}\text { Brussels- } \\
\text { Capital } \\
\text { Region }\end{array}$ & $\begin{array}{c}\text { Environment: } \\
\text { Green } \\
\text { Economy }\end{array}$ & $\begin{array}{c}\text { CE as part of strategy. } \\
\text { Bottom-up process, } \\
\text { companies directly } \\
\text { involved. }\end{array}$ & Ongoing actions. & $\begin{array}{l}\text { CE projects } \\
\text { funded with } \\
\text { European } \\
\text { Structural Funds } \\
\text { (ESF). }\end{array}$ & $\begin{array}{l}\text { Update } \\
\text { upcoming, } \\
\text { continuous } \\
\text { process. } \\
\text { No targets. }\end{array}$ \\
\hline Denmark & $\begin{array}{c}\text { Central } \\
\text { Denmark }\end{array}$ & $\begin{array}{l}\text { Growth } \\
\text { drivers }\end{array}$ & $\begin{array}{c}\text { CE as part of } \\
\text { business } \\
\text { development strategy. } \\
\text { Bottom-up } \\
\text { process/dialogue, } \\
\text { companies directly } \\
\text { involved. }\end{array}$ & $\begin{array}{l}\text { Action plans for } \\
\text { each initiative } \\
\text { (subpriority). } \\
\text { Ongoing actions. }\end{array}$ & $\begin{array}{l}\text { CE projects } \\
\text { funded by ESF, } \\
\text { other regional } \\
\text { and EU funding. }\end{array}$ & $\begin{array}{l}\text { No specified } \\
\text { regional targets. } \\
\text { Update in } \\
\text { progress. }\end{array}$ \\
\hline Finland & $\begin{array}{l}\text { Southwest } \\
\text { Finland }\end{array}$ & $\begin{array}{l}\text { Innovative } \\
\text { food chains }\end{array}$ & $\begin{array}{l}\text { CE roadmap } \\
\text { including defined } \\
\text { categories. } \\
\text { Bottom-up process. }\end{array}$ & $\begin{array}{l}\text { Action plans for } \\
\text { subpriorities. } \\
\text { Ongoing actions. }\end{array}$ & $\begin{array}{l}\text { S3 related } \\
\text { projects funded } \\
\text { by ESF, other } \\
\text { regional, } \\
\text { national and EU } \\
\text { funding. }\end{array}$ & $\begin{array}{l}\text { CE roadmap } \\
\text { update in } \\
\text { progress. } \\
\text { Targets under } \\
\text { preparation. }\end{array}$ \\
\hline Finland & Häme & $\begin{array}{l}\text { Sustainable } \\
\text { use of natural } \\
\text { resources }\end{array}$ & $\begin{array}{l}\text { CE roadmap under } \\
\text { preparation. } \\
\text { Bottom-up and } \\
\text { top-down approach. }\end{array}$ & Ongoing actions. & $\begin{array}{l}\text { CE projects } \\
\text { funded by ESF, } \\
\text { other regional, } \\
\text { national and EU } \\
\text { funding. }\end{array}$ & No targets. \\
\hline Finland & Päijät-Häme & $\begin{array}{l}\text { Circular } \\
\text { economy }\end{array}$ & $\begin{array}{l}\text { CE roadmap with } \\
\text { subpriorities defined. } \\
\text { Bottom-up and } \\
\text { top-down approach, } \\
\text { companies directly } \\
\text { involved. }\end{array}$ & $\begin{array}{l}\text { Action plan for } \\
\text { one subpriority, } \\
\text { others under } \\
\text { development. } \\
\text { Ongoing actions. }\end{array}$ & $\begin{array}{l}\text { CE and S3 } \\
\text { related projects } \\
\text { funded by ESF, } \\
\text { other regional, } \\
\text { national and EU } \\
\text { funding. }\end{array}$ & $\begin{array}{l}\text { CE roadmap } \\
\text { updated } \\
\text { annually. } \\
\text { Targets for one } \\
\text { subpriority, } \\
\text { others under } \\
\text { discussion. }\end{array}$ \\
\hline
\end{tabular}


Table 2. Cont.

\begin{tabular}{|c|c|c|c|c|c|c|}
\hline \multirow[b]{2}{*}{ Country } & \multirow[b]{2}{*}{ Region } & \multirow{2}{*}{$\begin{array}{c}\text { Planning } \\
\text { Thematic } \\
\text { Priority Area }\end{array}$} & \multicolumn{4}{|c|}{ Construction of Transformative Activities } \\
\hline & & & Roadmap & Action Plans & Funding & $\begin{array}{l}\text { Monitoring and } \\
\text { Evaluation }\end{array}$ \\
\hline Finland & Satakunta & $\begin{array}{l}\text { Bio and } \\
\text { circular } \\
\text { economy }\end{array}$ & $\begin{array}{l}\text { Growth programme } \\
\text { for bio and circular } \\
\text { economy. } \\
\text { Bottom-up process. }\end{array}$ & $\begin{array}{l}\text { Actions defined } \\
\text { in growth } \\
\text { programme. } \\
\text { Ongoing actions. }\end{array}$ & $\begin{array}{l}\text { CE and S3 } \\
\text { related projects } \\
\text { funded by ESF, } \\
\text { other regional, } \\
\text { national and EU } \\
\text { funding. }\end{array}$ & $\begin{array}{l}\text { Annual update } \\
\text { of growth } \\
\text { programme. } \\
\text { General-level } \\
\text { targets defined. }\end{array}$ \\
\hline Germany & Berlin & $\begin{array}{c}\text { Clean } \\
\text { technologies }\end{array}$ & $\begin{array}{c}\text { CE as part of strategy. } \\
\text { Cross-sector } \\
\text { approach, } \\
\text { bottom-up process, } \\
\text { companies directly } \\
\text { involved. }\end{array}$ & Ongoing actions. & $\begin{array}{c}\text { S3 related } \\
\text { projects funded, } \\
\text { not specifically } \\
\text { CE. }\end{array}$ & $\begin{array}{l}\text { Updates with no } \\
\text { specific schedule. } \\
\text { No targets } \\
\text { concerning CE. }\end{array}$ \\
\hline Germany & Brandenburg & $\begin{array}{c}\text { Clean } \\
\text { technologies }\end{array}$ & $\begin{array}{c}\text { CE as part of strategy. } \\
\text { Cross-sector } \\
\text { approach, } \\
\text { bottom-up process, } \\
\text { companies directly } \\
\text { involved. }\end{array}$ & Ongoing actions. & $\begin{array}{l}\text { Funding from } \\
\text { ESF is linked } \\
\text { with } \\
\text { masterplans. }\end{array}$ & $\begin{array}{l}\text { Updates with no } \\
\text { specific schedule. } \\
\text { No targets } \\
\text { concerning CE. }\end{array}$ \\
\hline Luxembourg & Luxembourg & $\begin{array}{l}\text { Clean \& eco- } \\
\text { technologies }\end{array}$ & $\begin{array}{l}\text { CE integrated into } \\
\text { broad goals. CE } \\
\text { strategy under } \\
\text { preparation. } \\
\text { Bottom-up and } \\
\text { top-down approach. }\end{array}$ & Ongoing actions. & $\begin{array}{l}\text { No ESF available } \\
\text { from CE. } \\
\text { National and EU } \\
\text { funding. }\end{array}$ & $\begin{array}{l}\text { No specific } \\
\text { update process } \\
\text { for CE defined } \\
\text { yet. Targets } \\
\text { defined for one } \\
\text { subpriority. }\end{array}$ \\
\hline Romania & $\begin{array}{l}\text { Sud- } \\
\text { Muntenia }\end{array}$ & $\begin{array}{l}\text { Bioeconomy: } \\
\text { Developing } \\
\text { circular } \\
\text { economy }\end{array}$ & $\begin{array}{l}\text { Defining of priorities } \\
\text { in progress. } \\
\text { Bottom-up process. }\end{array}$ & $\begin{array}{l}\text { Lack of CE actors } \\
\text { for actions. }\end{array}$ & $\begin{array}{l}\text { CE projects } \\
\text { funded by ESF, } \\
\text { other EU } \\
\text { funding. }\end{array}$ & $\begin{array}{l}\text { Update in } \\
\text { progress. } \\
\text { No targets } \\
\text { defined yet. }\end{array}$ \\
\hline Slovenia & Slovenia & $\begin{array}{l}\text { Networks for } \\
\text { the transition } \\
\text { to circular } \\
\text { economy }\end{array}$ & $\begin{array}{c}\text { Roadmap with } \\
\text { priority areas defined. } \\
\text { Bottom-up process, } \\
\text { companies directly } \\
\text { involved. }\end{array}$ & $\begin{array}{l}\text { Strategic research } \\
\text { and innovation } \\
\text { partnerships' } \\
\text { action plan for } \\
\text { transition to CE. } \\
\text { Ongoing actions. }\end{array}$ & $\begin{array}{l}\text { CE projects } \\
\text { funded from } \\
\text { cohesion fund, } \\
\text { national and } \\
\text { other EU } \\
\text { funding. }\end{array}$ & $\begin{array}{c}\text { Evaluation in } \\
\text { process. Targets } \\
\text { defined. }\end{array}$ \\
\hline Spain & $\begin{array}{l}\text { Basque } \\
\text { Country }\end{array}$ & $\begin{array}{l}\text { Building a } \\
\text { new circular } \\
\text { economy }\end{array}$ & $\begin{array}{l}\text { CE strategy almost } \\
\text { final. } \\
\text { Bottom-up process, } \\
\text { intense stakeholder } \\
\text { involvement, } \\
\text { companies directly } \\
\text { involved. }\end{array}$ & $\begin{array}{c}\text { Action plan } \\
\text { under } \\
\text { preparation. } \\
\text { Ongoing actions. }\end{array}$ & $\begin{array}{l}\text { No ESF } \\
\text { available. } \\
\text { Regional } \\
\text { funding. }\end{array}$ & $\begin{array}{l}\text { Updated every } \\
2.5 \text { and } 5 \text { years. } \\
\text { Targets under } \\
\text { preparation. }\end{array}$ \\
\hline
\end{tabular}

\subsection{Thematic Priority Areas}

The S3 process begins with identifying the thematic priority areas. Table 2 shows the thematic priority areas and the construction of transformative activities related to the $\mathrm{CE}$ for the regions in focus. The thematic priority areas reflect the $\mathrm{CE}$ through naming either directly or indirectly through subpriorities. The results for the search term 'circular economy' on the JRC's platform also included regions where CE is not present in the priority's name but is mentioned in the description of the priority. As Table 2 shows, five of the regions have $\mathrm{CE}$ in the name of the thematic priority area [52]. The differences in the naming of the priority reflect the background and wide perspective of the multiple aspects in which the $\mathrm{CE}$ is framed in general and as part of innovation policy. The recent 
development of the terminology behind CE is shown in the names of the thematic priorities; 'clean technologies', 'green economy' and 'sustainable use of natural resources' reflects the roots of the CE. However, from a totally different S3 perspective, one region has defined the $\mathrm{CE}$ as being one of the boosters in their priority 'growth drivers'.

Studying the thematic priorities as a basic element of the research setting shows that the regions have different starting points for how visible the link between CE and S3 can be. The five regions naming the $\mathrm{CE}$ as a thematic priority have a clear political mandate for proceeding further with the construction of transformative activities. Nevertheless, the policy and strategy structures related to the $\mathrm{CE}$ in the other seven regions also support S3 as it is mentioned in the description of the regional priorities.

As Foray [45] pointed out, too broad of a definition of the thematic priority area can make it difficult to generate the crucial density and agglomeration effects of S3. From the perspective of this research, it can be discussed to what degree and under what kinds of circumstances the concept of the $\mathrm{CE}$ fits this definition. The $\mathrm{CE}$ is surely seen as a potential direction of change in the regions involved; however, its broadness can create a challenge. In the cases where the thematic priority is quite broad, the importance of translating it into a transformational roadmap and a transparent action plan becomes even more vital.

\subsection{Roadmaps for Concretising $S 3$}

As Foray [45] described, S3 priority areas should be further translated into transformational roadmaps. This is the crucial phase of the $\mathrm{S} 3$ process because many regions have had difficulties implementing the priorities. In this research, the focus was specifically on the S3 strategies or roadmaps related to the CE. Due to the regional differences in naming thematic priority areas, the roadmap phase is not completely comparable as some regional priorities are not specifically targeted on CE. Hence, the interviews were important in supporting the understanding of the regional differences.

In the interviews, the regional approach to the $\mathrm{CE}$ as a part of $\mathrm{S} 3$ was determined. All regions have defined regional CE priorities, which, in most cases, are already concretised in a strategy document. Six of the studied regions (Brussels, Central Denmark, Southwest Finland, Päijät-Häme, Satakunta, Slovenia) have a roadmap, in the meaning of a strategy or a programme where the regional CE targets are defined. In some of these regions, the roadmap or the strategy can be seen to tightly define S3 priorities: 'The circular economy roadmap has specified the regional priorities [of the S3]' (8). However, all regions do not necessarily see the CE strategy document as defining the $\mathrm{S} 3$ thematic priority of, or related to, the CE. In some regions, the CE strategy is a parallel document, which only partly overlaps the S3: 'One of the components of this strategy [S3] is to further develop research and innovation in the field of the environment and more specifically the circular economy. And we also have this circular economy plan, so for research and innovation those two plans overlap' (1). In some cases, the S3 and CE roadmaps are seen as separate documents: 'We have two plans that are working side by side here, the roadmap [towards CE] and the smart specialisation strategy' (6). In four of the regions, a roadmap or strategy related to the $C E$ is in preparation (Häme, Luxembourg, Sud-Muntenia, Basque Country). In the two remaining regions, the $\mathrm{CE}$ plays an important horizontal role in several sectors, even if it does not have its own roadmap (Berlin, Brandenburg).

In the five regions where the $C E$ is mentioned in the name of the thematic priority area, a CE roadmap (named also CE strategy or growth programme with specified regional priorities) either exists (Päijät-Häme, Satakunta, Slovenia), is almost finalised (Basque Country) or is in the planning phase (Sud-Muntenia). This could mean that the thematic priority status given through the naming can speed up the roadmap process. However, based on the interviews, in some regions, the roadmap does not clearly define the S3 priority but rather promotes regional CE possibilities in general.

The main characteristic of S3 as a policy process is the combination of the top-down and bottom-up components [45]. According to Navarro [45], typically, the process of setting priorities has been led by regional governments (top-down) and involves a participatory 
aspect. The top-down approach is suitable when the priority area is chosen [45]. However, in the roadmap and action plan phases, the entrepreneurial discovery logic becomes especially important [45]. Even though an equal and well-organised EDP is not easy to accomplish as political and social interests of stakeholders emerge [29]. The challenges related to the EDP are touched in several studies and provide its own area of research $[28,29]$. The findings of this research confirm that the EDP has been taken seriously when defining the $\mathrm{CE}$ roadmaps. The interviews pointed out that the process has been mainly led by the regional authority, and some regions mention the top-down element; however, all the roadmaps have been set up or are in the process of being prepared in a bottom-up approach. One of the interviewees described this quite clearly:

So the top-down part is 'Well, these are the sectors that we consider important and that we know are most innovative so that's why we want to define them as our RIS3', and then, we invited research institutions and other companies and other stakeholders in order to define which topics are important within the specific sectors (3).

All regions included in this research have proceeded with a bottom-up approach to define roadmaps related to the $\mathrm{CE}$. The bottom-up processes were described as including administration and academia, development organisations or associations, and in most cases, the private sector. The cooperation has mainly been organised through workshops, focus groups or other kinds of meetings. However, face-to-face communication, such as interviews and discussions with the stakeholders, has also been undertaken in a few regions: 'We have organised focus groups for each priority, involving the Ministry, research institutes, universities, association of [a specific sector], entrepreneurs, chambers of commerce, public authorities, a municipality' (11).

There were examples of regions having an outside actor that was responsible for facilitating the roadmap process in practice, for example, a university (Päijät-Häme) or chamber of commerce (Slovenia). In Central Denmark, the process was implemented by a consultant specifically responsible for communicating with the private sector. Furthermore, two regions mentioned the involvement of citizens in their strategy processes: 'We included all levels of administration; we also integrated the private sector; we invited the clusters; we invited the companies, also private. Finally, the citizenship was also called to the participations' (5).

\subsection{Actions, Monitoring and Evaluation}

When the priority areas have been translated into roadmaps, the next step is to form action plans to implement the activities. Action plans mean strategy documents including information related to funding research, development and innovation activities, investments, actors (names of organisations) involved in the actions, schedules, monitoring and evaluation of the results, as well as a plan for 'feedback' i.e., updating the content [45]. From the CE perspective, only two regions (Satakunta and Slovenia) have refined their CE roadmaps into action plans. As mentioned above, these two regions are among the five that have defined the $C E$ in their thematic priorities. In two regions (Southwest Finland and Päijät-Häme), actions were defined for some specific parts of the $\mathrm{CE}$; for example, Päijät-Häme has defined an action plan for the subpriority 'bio-based $\mathrm{CE}^{\prime}$. As defined in Table 2, no specific action plan exists in the majority of the regions, but in all the regions, $\mathrm{CE}$ actions are ongoing. However, due to the differences in the thematic priority areas, the regions are not completely comparable.

In all regions, the funding of CE-related projects is taking place. As Table 2 shows, the link between S3 priorities and the ESF is obvious in the regions where ESF is available. Moreover, several regions mentioned that other types of funding for developing $\mathrm{CE}$ are utilised. Nevertheless, in several regions the S3 was adopted quite late with regards to the programming period 2014-2020. Due to this it was not translated into budgetary provisions. This might have influenced how strategic and well connected the funded actions have been. However, as the S3 strategies continue to guide the allocation of ESIF funding to specific themes or activities also during the new funding period 2021-2027, having CE as 
a defined part of S3 may increase the availability of funding for implementation and CE related projects in the future.

For most regions, the monitoring and evaluation of the CE roadmaps and action plans are in the development phase. This finding supports the conclusions of previous studies implying that regions have very varying approaches to monitoring and evaluation, and that this phase is in many regions only under development $[34,35]$. Of the regions that identified $\mathrm{CE}$ as a specific thematic priority and where action plans have been prepared, Satakunta and Slovenia have defined targets to measure the CE. In Päijät-Häme, where the action plan has been defined for one subpriority, targets also exist for this specific part. The other regions do not have defined targets, or they are in the preparation phase.

Regarding the updating of CE roadmaps, only three regions seem to have a clear answer and active updating process. In Satakunta and Päijät-Häme, annual updates occur, and in the Basque Country, an update every two and a half years is planned. However, the majority of the studied regions either conduct continuous updates in the form of checking the priorities when funding new projects or looking at CE priorities when the general regional-level programme (or S3) is updated. Otherwise, they do not have any specific update process for the $\mathrm{CE}$ content. The monitoring and evaluation of roadmaps or action plans seem to be somewhat challenging to define.

\section{Conclusions}

To react to the severe challenges of sustainability in today's world, the CE is seen as a solution. When facing this entity at the regional level, policies and strategies are needed. This article explains how the CE is concretised in S3's of 12 European regions. It provides an attempt to clarify the actual stage of development in the regional innovation policy from the CE perspective, and how the S3 as a policy framework has been utilised around Europe in promoting $\mathrm{CE}$ in the regions.

S3 have existed in European countries since the early 2010s but concretising the chosen strategic priority areas into regional activities remains a challenge. As we have seen, only a couple of the studied regions have achieved setting up regional action plans in the S3 process. This research revealed that some regions see the S3 process strictly as fostering innovation and not as a strategic tool for developing the $\mathrm{CE}$ in their region, even if the themes overlap. The aim of S3 is to improve the sectors concerned and to transform the existing economic structures with the support of research, development and innovation. Furthermore, the linkage between CE and S3 is reinforced by the ESIF and distribution of regional funding: if the $\mathrm{CE}$ is visible in the $\mathrm{S} 3$, regional research, development and innovation projects in the theme are naturally supported. S3 should build on regional strengths, but 'new openings' are also absolutely applicable to the CE. To support the $\mathrm{CE}$ in the regions, the regional cluster strategies could more efficiently and innovatively be combined with S3 to minimise the situation in which the regions are spreading their efforts too broadly by having partly parallel and overlapping strategies to address the same topic. This combination would also help clarify the S3 and bring the still somewhat abstract concept closer to other regional strategies. Thus, the transformation and direction of change should lead the process.

All the studied regions have included a bottom-up approach or are aiming to proceed in this direction to define the CE roadmap. The bottom-up process was described as including public sector actors, such as authorities, academia, development organisations, associations and, in many cases, private companies. This study confirms the idea that when it comes to the implementation of regional strategies, the participatory nature of activities should be highlighted. Yet, the depth of participation, or the actual contribution of the participation from the transformation point of view, was not targeted in the interview questions. An interesting question for future research would be: Does the bottom truly meet the top?

S3 should be supported by monitoring and evaluation tools to measure performance $[8,34,45]$. However, the monitoring of roadmaps and action plans is challenging 
because of the difficulties in defining and setting CE targets. Moreover, the S3 concept itself is new, and the regions do not have much experience to share related to monitoring the development and success of S3 priority areas in the regional and spatial contexts. Being able to monitor the direction of change can also make the change more manageable from the regional development and policy point of view.

As a limitation of this study, it should be noted that not all European regions with the $\mathrm{CE}$ as an innovation priority have shared their information on the JRC's database. The database is constantly developing, and regions update their S3 information. Also, after the interview phase, some data were found to already be outdated at the point of research; for example, Berlin had updated its thematic priorities, but the information was not yet available on the database. As we have seen, both S3 and CE are constantly evolving concepts, which sets challenges for empirical studies. It should also be noted that as S3 strategies and processes are always based on region-specific institutional and governance context as well as long and varying industrial and economic histories $[36,42,46]$, it was not feasible to study the target regions in as detailed level as it would be possible in a case study or in a cross-case analysis of only a few regions. However, the strength of the chosen methodological approach of this study lies in the EU-wide examination and the coherent multi-country comparison.

This study contributes to the previous S3 literature by presenting a conceptual framework for analysing the S3 process and policy implementation, which also enables interregional comparisons. Based on the analysed data, many regions have the $\mathrm{CE}$ as a chosen priority area in their S3. Unless these prioritised themes are concretised and connected to the regional entrepreneurial bases and innovation activities, the S3 remains no more than a regional branding effort. An updated S3 framework which moves from planning to the concrete construction of transformative activities can work as a useful framework in regions, regardless of whether it is labelled as regional S3 work. The framework integrates the latest conceptual discussion of S3 with practice-level regional innovation policy activities and can be utilised as a part of practical policy and strategy planning processes in regions as an alternative to the original six-stepped S3 process [8].

The empirical part of this study not only presents the state-of-the-art of S3 within the CE priority area but also highlights the gaps and challenges in promoting ambitious crosssectoral priority areas as well as where these challenges originate from. The results reveal how the $\mathrm{CE}$ is concretised through the S3 process and implementation in European regions and show the potential of utilising the S3 policy approach in combining sustainability-based goals and regional economic development.

The S3 themes should be based on regional strengths but be flexible to meet the changing requirements for moving the region forward. Based on this study, it is recommended that in order to maximise the benefits of both $\mathrm{S} 3$ and the $\mathrm{CE}$, regions should focus on clearly defined priorities and concrete-yet adjustable and flexible enough-plans on how to achieve the set targets. Furthermore, the possibilities for synergies should be recognised. Due to the novelty of both the CE and S3, the concepts are still in development, and the regions do not yet have mature practices with a combination that can be shared. Despite the challenges, promoting the $\mathrm{CE}$ as a strategic priority through the $\mathrm{S} 3$ process has developed regional abilities in defining $\mathrm{CE}$ targets and actions by focusing on existing strengths and future potential.

Author Contributions: Conceptualisation, S.V., S.R. and K.M.; methodology, S.V., S.R. and K.M.; validation, S.V., S.R. and K.M.; formal analysis, S.V.; investigation, S.V.; resources, S.V.; data curation, S.V.; writing — original draft preparation, S.V., S.R. and K.M.; writing-review and editing, S.V., S.R. and K.M.; visualisation, S.V. and S.R.; supervision, K.M.; project administration, K.M.; funding acquisition, K.M. All authors have read and agreed to the published version of the manuscript.

Funding: This research received no external funding.

Institutional Review Board Statement: Ethical review and approval were waived for this study due to the fact that participation was voluntary and interview data was anonymous. 
Informed Consent Statement: Informed consent was obtained from all subjects involved in the study.

Data Availability Statement: The data presented in this study are available on request from the corresponding author. The data are not publicly available due to privacy reasons.

Conflicts of Interest: The authors declare no conflict of interest.

\section{Appendix A}

Interview questions: Concretising Circular Economy in European Smart Specialisation Strategies

Background

1. Name of the region in focus

2. When was circular economy (CE) chosen as an $\mathrm{S} 3$ priority in your region? (year)

3. Why was CE chosen as a RIS3 priority in your region? Please describe the background and regional strengths.

Priorities and targets

4. Have you specified regional priorities to reach CE?

5. If yes,

a. please name the priorities

b. Have you specified measurable targets for your CE priorities?

c. Have you specified concrete actions for reaching your CE priorities? If yes, please mention examples

d. How where the CE priorities defined? (e.g., responsible body, bottom up/top down, stakeholder involvement)

e. Have you defined a process for updating the CE content in your S3?

f. If yes, please shortly describe (responsible body, stakeholder involvement, frequency)

6. If no,

a. Why are the priorities not defined?

b. Are you planning to define the priorities?

Funding circular economy development

7. Which sources of funding has enabled promoting CE in your region?

8. What is the proportion of structural fund projects promoting CE related to all approved structural fund projects in your region?

9. Is there a link between the S3 and the extent of financed CE projects?

10. Any additional comments

\section{References}

1. OECD: Farm Management Practices to Foster Green Growth. Available online: http://www.oecd.org/publications/farmmanagement-practices-to-foster-green-growth-9789264238657-en.htm (accessed on 20 June 2020).

2. Geng, Y.; Fu, J.; Sarkis, J.; Xue, B. Towards a national circular economy indicator system in China: An evaluation and critical analysis. J. Clean. Prod. 2012, 23, 216-224. [CrossRef]

3. Ghisellini, P.; Cialani, C.; Ulgiati, S. A review on circular economy: The expected transition to a balanced interplay of environmental and economic systems. J. Clean. Prod. 2016, 114, 11-32. [CrossRef]

4. Kirchherr, J.; Reike, D.; Hekkert, M. Conceptualizing the circular economy: An analysis of 114 definitions. Resour. Conserv. Recycl. 2017, 127, 221-232. [CrossRef]

5. European Commission: Closing the Loop—An EU Action Plan for the Circular Economy. COM(2015) 614 Final. Available online: http:/ / eur-lex.europa.eu/legal-content/EN/TXT/?uri=CELEX\%3A52015DC0614 (accessed on 22 June 2020).

6. European Commission: A new Circular Economy Action Plan. For a Cleaner and More Competitive Europe. COM(2020) 98 Final. Available online: https:/ / eur-lex.europa.eu/legal-content/EN/TXT/?qid=1583933814386\&uri=COM:2020:98:FIN (accessed on 22 June 2020).

7. UNEP: Towards a Green Economy: Pathways to Sustainable Development and Poverty Eradication. Available online: http://web. unep.org/greeneconomy/sites/unep.Org.greeneconomy/files/field/image/green_economyreport_final_dec2011.pdf (accessed on 20 October 2020). 
8. Foray, D.; Gobbard, J.; Beldarrain, X.G.; Landabaso, M.; McCann, P.; Morgan, K.; Nauwelaers, C.; Ortega-Argilés, R. Guide to Research and Innovation Strategies for Smart Specialisation (RIS3). European Commission. Available online: http:/ / ec.europa. eu/regional_policy/sources/docgener/presenta/smart_specialisation/smart_ris3_2012.pdf (accessed on 22 October 2020).

9. Foray, D.; van Ark, B. Smart Specialisation in a Truly Integrated Research Area Is the Key to Attracting More R\&D to Europe. Knowledge Economists Policy Brief No. 1. Available online: http:/ / ec.europa.eu/invest-inresearch/pdf/download_en/policy_ brief1.pdf (accessed on 20 June 2020).

10. Ellen MacArthur Foundation: Towards the Circular Economy Vol. 1: An Economic and Business Rationale for an Accelerated Transition. Available online: https:/ / www.ellenmacarthurfoundation.org/assets/downloads/publications / Ellen-MacArthurFoundation-Towards-the-Circular-Economy-vol.1.pdf (accessed on 20 October 2020).

11. Rizos, V.; Tuokko, K.; Behrens, A. The Circular Economy: A Review of Definitions, Processes and Impacts. CEPS Research Reports. Available online: http:/ / aei.pitt.edu/85892/1/RR2017-08_CircularEconomy_0.pdf (accessed on 9 October 2020).

12. Viles, E.; Santos, J.; Arévalo, T.F.; Tanco, M.; Kalemkerian, F. A new mindset for circular economy strategies: Case studies of circularity in the use of water. Sustainability 2020, 12, 9781. [CrossRef]

13. Maranesi, C.; De Giovanni, P. Modern circular economy: Corporate strategy, supply chain, and industrial symbiosis. Sustainability 2020, 12, 9383. [CrossRef]

14. Barreiro-Gen, M.; Lozano, R. How circular is the circular economy? Analysing the implementation of circular economy in organisations. Bus. Strategy Envrion. 2020, 29, 3484-3494. [CrossRef]

15. Sánchez-Ortiz, J.; Rodríguez-Cornejo, V.; Del Río-Sánchez, R.; García-Valderrama, T. Indicators to measure efficiency in circular economies. Sustainability 2020, 12, 4483. [CrossRef]

16. Saidani, M.; Yannou, B.; Leroy, Y.; Cluzel, F.; Kendall, A. A taxonomy of circular economy indicators. J. Clean. Prod. 2019, 207, 542-559. [CrossRef]

17. European Commission: Report on the Implementation of the Circular Economy Action Plan. COM(2019) 190 Final. Available online: https:/ / eur-lex.europa.eu/legal-content/EN/TXT/?qid=1551871195772\&uri=CELEX:52019DC0190 (accessed on 10 November 2020).

18. Vanhamäki, S.; Medkova, K.; Malamakis, A.; Marisova, E.; Huisman, D.; Moussiopoulos, N. Bio-based circular economy in European national and regional strategies. Int. J. Sust. Dev. Plan. 2019, 14, 31-43. [CrossRef]

19. Vanhamäki, S.; Virtanen, M.; Luste, S.; Manskinen, K. Transition towards a circular economy at a regional level: A case study on closing biological loops. Resour. Conserv. Recycl. 2020, 156. [CrossRef]

20. European Commission: The European Green Deal. COM(2019) 640 Final. Available online: https://ec.europa.eu/info/sites/ info/files/european-green-deal-communication_en.pdf (accessed on 10 November 2020).

21. European Commission: Industrial Pollution, European Solutions: Clean Technologies-LIFE and the Directive on Integrated Pollution Prevention and Control (IPPC Directive). Available online: https:/ / ec.europa.eu/environment/archives/life/publications/ lifepublications/lifefocus / documents / cleantech_en.pdf (accessed on 20 November 2020).

22. European Commission: The European Green Deal Investment Plan and Just Transition Mechanism. Available online: https: / / ec.europa.eu/info/publications/200114-european-green-deal-investment-plan_fi (accessed on 20 November 2020).

23. Saltelli, A.; Benini, L.; Funtowicz, S.; Giampietro, M.; Kaiser, M.; Reinert, B.; van der Sluijs, J.P. The technique is never neutral. How methodological choices condition the generation of narratives for sustainability. Environ. Sci. Policy 2020, 106, 87-98. [CrossRef]

24. Giampietro, M.; Funtowicz, S.O. From elite folk science to the policy legend of the circular economy. Environ. Sci. Policy 2020, 109, 64-72. [CrossRef]

25. European Commission: Directive 2008/98/EC of the European Parliament and the Council of 19 November 2008 on Waste and Repealing Certain Directives. Available online: http://eur-lex.europa.eu/legal-content/EN/TXT/PDF/?uri \protect\$ $\backslash$ relax $\backslash$ protect \begingroup1 \endgroup \@@over4\}\$CELEX:32008L0098\&from \protect\$ $\backslash$ relax $\backslash$ protect $\backslash$ begingroup1 \endgroup $\backslash @ @$ over4\}\$EN (accessed on 10 November 2020).

26. Korhonen, J.; Honkasalo, A.; Seppälä, J. Circular economy: The concept and its limitations. Ecol. Econ. 2018, 143, 37-46. [CrossRef]

27. Boschma, R.; Frenken, K. Technological relatedness and regional branching. In Dynamic Geographies of Knowledge Creation and Innovation; Bathelt, H., Feldman, M.P., Kogler, D.J., Eds.; Routledge, Taylor and Francis: Abingdon, UK, 2011 ; pp. 154-196.

28. Boschma, R. Constructing regional advantage and smart specialisation: Comparison of two European policy concepts. Sci. Reg. 2014, 13, 51-68. [CrossRef]

29. Hassink, R.; Gong, H. Six critical questions about smart specialization. Eur. Plan. Stud. 2019, 27, 2049-2065. [CrossRef]

30. European Commission: Cohesion Policy beyond 2020: Commission Helps Europe's Regions Become More Innovative. Press Release. Brussels, 19 June 2018. Available online: https:/ / ec.europa.eu/regional_policy / en/newsroom/news/2018/06/19-062018-cohesion-policy-beyond-2020-commission-helps-europe-s-regions-become-more-innovative (accessed on 10 November 2020).

31. McCann, P.; Ortega-Argilés, R. Modern regional innovation policy. Camb. J. Reg. Econ. Soc. 2013, 6, 187-216. [CrossRef]

32. Benner, M. From smart specialisation to smart experimentation: Building a new theoretical framework for regional policy of the European Union. Z. Wirtsch. 2014, 58, 33-49. [CrossRef]

33. Georghiou, L.; Elvira Uyarra, A.; Saliba Scerri, R.; Castillo, N.; Cassingena Harper, J. Adapting smart specialisation to a micro-economy-the case of Malta. Eur. J. Innov. Manag. 2014, 17, 428-447. [CrossRef] 
34. Paliokaite, A.; Martinaitis, Z.; Sarpong, D. Implementing smart specialisation roadmaps in Lithuania: Lost in translation? Technol. Forecast. Soc. Chang. 2016, 110, 143-152. [CrossRef]

35. Teräs, J.; Mäenpää, A. Smart specialisation implementation processes in the North. Eur. Struct. Investig. Funds J. 2016, 4, 75-86.

36. McCann, P.; Ortega-Argilés, R. Smart specialisation in European regions: Issues of strategy, institutions and implementation. Eur. J. Innov. Manag. 2014, 17, 409-427. [CrossRef]

37. Pugh, R. 'Old wine in new bottles'? Smart specialisation in Wales. Reg. Stud. Reg. Sci. 2014, 1, 152-157. [CrossRef]

38. Morgan, K. Nurturing novelty: Regional innovation policy in the age of smart specialisation. Environ. Plan. C Politics Space 2017, 35, 569-583. [CrossRef]

39. Pugh, R. Questioning the implementation of smart specialisation: Regional innovation policy and semi-autonomous regions. Environ. Plan. C Politics Space 2018, 36, 530-547. [CrossRef]

40. Fellnhofer, K. Visualized bibliometric mapping on smart specialization: A co-citation analysis. Int. J. Knowl.-Based Dev. 2018, 9, 76-99. [CrossRef]

41. McCann, P.; Ortega-Argilés, R. Smart specialization, regional growth and applications to European Union cohesion policy. Reg. Stud. 2015, 49, 1291-1302. [CrossRef]

42. Capello, R.; Kroll, H. From theory to practice in smart specialization strategy: Emerging limits and possible future trajectories. Eur. Plan. Stud. 2016, 24, 1393-1406. [CrossRef]

43. Oughton, C.; Landabaso, M.; Morgan, K. The regional innovation paradox: Innovation policy and industrial policy. J. Technol. Transf. 2002, 27, 97-110. [CrossRef]

44. Muscio, A.; Reid, A.; Rivera Leon, L. An empirical test of the regional innovation paradox: Can smart specialisation overcome the paradox in Central and Eastern Europe? J. Econ. Policy Reform 2015, 18, 153-171. [CrossRef]

45. Foray, D. In response to 'Six critical questions about smart specialization'. Eur. Plan. Stud. 2019, 27, 2066-2078. [CrossRef]

46. Rinkinen, S. Smart regional innovation policies-From cluster approaches to place-based policies. Int. J. Innov. Reg. Dev. 2015, 6, 204-218. [CrossRef]

47. Virkkala, S.; Mäenpää, A.; Mariussen, Å. A connectivity model as a potential tool for smart specialization strategies. Eur. Plan. Stud. 2017, 25, 661-679. [CrossRef]

48. Braun, V.; Clarke, V. Thematic analysis. In APA Handbook of Research Methods in Psychology: Vol. 2. Research Designs; Cooper, H., Ed.; Springer: Berlin/Heidelberg, Germany, 2012; pp. 57-71. [CrossRef]

49. Schmidt, C. The analysis of semi-structured interviews. In A Companion to Qualitative Research; Flick, U., von Kardorff, E., Steinke, I., Eds.; Sage: Glasgow, UK, 2004; pp. 253-258.

50. Galletta, A. Mastering the Semi-Structured Interview and Beyond: From Research Design to Analysis and Publication; NYU Press: New York, NY, USA; London, UK, 2013.

51. Hopf, C. Qualitative Interviews: An Overview. In A Companion to Qualitative Research; Flick, U., von Kardorff, E., Steinke, I., Eds.; Sage: Glasgow, UK, 2004; pp. 203-208.

52. European Commission Smart Specialisation Platform, Tools, Eye@RIS3. Available online: https://s3platform.jrc.ec.europa.eu/ map (accessed on 10 May 2019).

53. European Commission Smart Specialisation Platform, How Can Regions and Countries Join the S3 Platform? Available online: https: / s3platform.jrc.ec.europa.eu/registration (accessed on 27 December 2020).

54. European Commission Smart Specialisation Platform, Registered Countries and Regions in the S3 Platform. Available online: https:/ / s3platform.jrc.ec.europa.eu/s3-platform-registered-regions (accessed on 27 December 2020). 